\title{
SEED MORPHOMETRY AND GERMINATION OF Aechmea costantinii (Mez) L. B. Sm. (BROMELIACEAE) ${ }^{1}$
}

\author{
PETRÚCIO ALEXANDRE FONSECA RIOS ${ }^{2}$, JOAO CORREIA ARAÚJO NETO ${ }^{3 *}$, VILMA MARQUES FERREIRA ${ }^{3}$, \\ MARIA INAJAL RODRIGUES DA SILVA DAS NEVES ${ }^{3}$
}

\begin{abstract}
The potential economic and environmental benefits brought by bromeliads production are significant. It is noteworthy that the high degree of degradation of some ecosystems as the Atlantic forest involve reduction of these species. This factor has been worsened by the elevated degree of endemism of these plants, e.g. Aechmea costantinii (Mez) L. B. Sm., which is a high ornamental potential bromeliad but understudied. Thus, the present research aimed to characterize physical and morphological features of $A$. costantinii fruit and seeds, describing the different stages of post-seminal development, as well as evaluating seed germination behavior with respect to temperature and light. For this purpose, we used fruit and seeds freshly harvested from an Atlantic Forest fragment, located in the city of Maceió, Alagoas State, Brazil. Tests were carried out under a completely randomized design, in a 6x4 factorial scheme (temperature $\mathrm{x}$ light) with four replications of 25 seeds. The polyspermic fruit are of tricarpellate/triloculate type and originated from inferior ovary, containing an average of 73 elliptical and mucilaginous seeds with basal embryo. The germination is epigeal-type and occurs in a great intensity and high speed at $35{ }^{\circ} \mathrm{C}$, regardless light presence or quality.
\end{abstract}

Key words: Bromeliad. Light. Temperature. Atlantic forest.

\section{MORFOMETRIA E GERMINAÇÃO DE SEMENTES DE Aechmea costantinii (Mez) L. B. Sm. (BROMELIACEAE) ${ }^{1}$}

\begin{abstract}
RESUMO - O potencial econômico e os benefícios ambientais que as bromélias podem proporcionar por meio de sua produção são significantes. Salienta-se que em virtude do alto grau de degradação da Mata Atlântica, essas espécies têm sido reduzidas, fator agravado pelo elevado grau de endemismo destas, a exemplo da Aechmea costantinii (Mez) L. B. Sm., que é uma bromélia de alto potencial ornamental, porém pouco estudada. Dessa forma, o trabalho teve como objetivo a caracterização física e morfológica dos frutos e sementes, descrição das diferentes fases do desenvolvimento pós-seminal, bem como a avaliação do comportamento germinativo das sementes em função da temperatura e da luz. Para a condução do trabalho, utilizaram-se frutos e sementes recém colhidos de um fragmento de Mata Atlântica, no município de Maceió, Alagoas, Brasil. Os ensaios foram conduzidos sob delineamento inteiramente casualizado, em esquema fatorial 6x4 (temperatura $\mathrm{x}$ luz) com quatro repetições de 25 sementes. Os frutos polispérmicos do tipo tricarpelar/trilocular, indeiscentes, são originados de ovário ínfero, contendo em média 73 sementes elípticas, mucilaginosas, com embrião basal. A germinação é do tipo epígea, ocorrendo em maior intensidade e velocidade a $35{ }^{\circ} \mathrm{C}$, independente da presença e qualidade de luz.
\end{abstract}

Palavras-chave: Bromélia. Luz. Temperatura. Mata Atlântica.

\footnotetext{
*Corresponding author

${ }^{1}$ Received for publication in $03 / 24 / 2015$, accepted in $09 / 09 / 2015$.

Paper extracted from the master's thesis of the first autor.

${ }^{2}$ Instituto Federal de Alagoas, Campus Santana do Ipanema, Santana do Ipanema, AL, Brazil; pafrios@gmail.com.

${ }^{3}$ Center of agricultural Sciences, Universidade Federal de Alagoas, Rio Largo, AL, Brasil; jcanetto2@hotmail.com, vilmaferreira@ceca.ufal.br, inajal_18@hotmail.com.
} 


\section{INTRODUCTION}

The Bromeliaceae family includes 3,086 species divided into 58 genera (LUTHER, 2008), and also into eight subfamilies, which are Bromelioideae, Pitcairnioideae, Tillandsioideae, Puyoideae, Navioideae, Hechtioideae, Lindmanioideae, Brocchinioideae, classified by floral and morphological characteristics of fruit and seeds (GAVINISH et al. 2007).

These plants are an important flora and physiognomy component of Brazilian ecosystems, sheltering around $36 \%$ of the cataloged species, contributing significantly to biodiversity of these communities (BENZING, 2000). Especially the Atlantic Forest, which has more than half of all known species. Nevertheless, it is noteworthy mention that certain circumstances as the high degree of endemism, Atlantic Forest degradation and fragmentation, which houses near $81.8 \%$ of the known species, combined with deforestation and indiscriminant extraction have considerably increased endangering of several bromeliad species. Additionally, predatory sampling for commercialization and depredation of natural environments are taken as the main cause of extinction or drastic reduction of numerous species (PEREIRA et al., 2008). Among these species, we can mention Aechmea costantinii that is endemic to the Atlantic Forest within Northeastern São Francisco River, which encompass the states of Alagoas, Pernambuco, Paraíba and Rio Grande do Norte in Brazil. This specimen occurs preferably as epiphyte at the forest upper-middle stratum in mountainous areas, including high wetlands in the states of Paraiba and Pernambuco. In the state of Alagoas, this species occurs along the coast above 400-meter altitude, with the exception of a population established in the environmental protection area of Catole in Satuba, near the state capital (SIQUEIRA FILHO; HELM, 2006). The plant has pinkish coriaceous leaves, which are disposed in a funnel-shaped basal rosette. The leaves have an asymmetric acute and apiculate apex with dense to sub-dense thorny margins, being narrowly triangular. Erect, reddish scape, having roses and reddish scape bracts. The flowers are odorless, with sublinear-lanceolate petals, free, erect, except for the apex, which is sub-erectus at anthesis, forming a tubular corolla with vibrant color (RIOS et al., 2010).

Despite the ecological importance of the Bromeliaceae family and considering its great diversity, there is little knowledge on its propagation structures and seed germination behavior in terms of environmental factors, such as light and temperature demands.

Thus, studies related to internal and/ or external morphological structures of seeds, seedlings and fruit are of major importance to differentiate taxonomic groups, and consequently conduct germination and vigor tests for seed conservation. In addition, such studies would improve understanding of the regeneration of these plants in natural ecosystems, since the emergence and seedling establishment are critical stages in their life cycle (FONTENELLE et al., 2007; SILVA; MÔRO, 2008).

Thus, the knowledge on the morphology of seedlings is the basis for succession and regeneration studies of natural ecosystems, referring the seedlings as a functional adaptation to the environment and are associated with environmental factors, such as mother plant lifecycle, seed dispersibility and regeneration strategies, which justifies the characterization studies (PEREIRA et al., 2008; OLIVEIRA et al., 2012).

Research focused on fruit, seeds and seedlings of bromeliads under several issues are scarce in the literature. This way, we aimed at characterizing the fruit and seed morphology of $A$. costantinii, describing the different phases of postseminal development and studying the seed germination under varied conditions of light and temperature.

\section{MATERIAL AND METHODS}

The research was carried out in the laboratory of Seed Analysis located in located in the Center of Agricultural Sciences (CECA) of the Federal University of Alagoas (UFAL), in Rio Largo-AL, Brazil.

Fruits and seeds were harvested from specimens found in an area of permanent preservation belonging to the Cachoeira do Meirim Sugar and Ethanol Plant, which is around $20 \mathrm{~km}$ far from the urban area of Maceió (state capital). The area is cartographically located at the geographic coordinates of $09^{\circ} 22^{\prime}$ south latitude and $35^{\circ} 43^{\prime}$ west longitude, at an altitude range of 120-304 m (ASSIS, 2000).

Between December 2008 and May 2009, we selected 15 terrestrial and rupicolous specimens of $A$. costantinii at blossoming stage, removing a single sprout per clump, spaced from one another by 10 meters.

In the early fruiting, when the selected individuals no longer had flowers or flower buds, (June 2009), we isolated inflorescences by wrapping them with tulle bags; each plant was labeled and numbered. This procedure was carried out to avoid fruit withdrawal and/ or damages caused by seed dispersers and predators.

During the sampling, we have observed fruit at different ripeness stages within the same plant. Therefore, we harvested ripe fruits weekly, collecting an average of 10 fruits of each mother plant. 
Seeds were removed out from fruit manually. All mucilage involving seeds was taken away with a paper towel aid to prevent microbial proliferation. Subsequently, wholesome and normal seeds were selected and packed into Kraft paper bags, previously identified with sampling date and species. The samples were stored in dry chamber set at $23 \pm$ $3{ }^{\circ} \mathrm{C}$ and air relative humidity around $60 \%$.

Sixty ripe and healthy fruit, with no deformation, were measured for length, width, and thickness, by using a digital caliper, for morphometric characterization. The same measurements were performed in 150 whole seeds 15 different individuals, according to methodology adopted by Pereira et al. (2008).

Regarding the external and internal pericarp aspects, we evaluated color, texture, consistency, hairiness, brightness, among other possible features through a table magnifying glass.

Seed morpho-anatomical observations were made through free-hand-made longitudinal sections, using scalpel blades and with the aid of microtome, after embedding them in histological wax. Subsequently, we observed the internal characteristics under binocular stereomicroscope and magnifying glass. It was observed endosperm presence, consistency and color, as well as embryo location, color, size and position, according to method described by Áquila (2004).

Seed external characterization was performed according to procedures adopted by Pereira et al. (2008), in which we analyzed integument color, texture, and consistency. The thousand seed weight was obtained multiplying the average of eight 100whole-seed weightings by 10 , which were freshly harvested and chosen at random (BRASIL, 2009). The average number of seeds per fruit was also determined. For each variable, we calculated mean, mode, median, standard deviation, minimum and maximum values, aside from variation coefficient. Seed moisture content was determined by the oven method at $105{ }^{\circ} \mathrm{C}$ for $24 \mathrm{~h}$, according to requirements of the Brazilian Rules for Seed Analysis (BRASIL, 2009).

Aiming at recording the different stages of post-seminal development, we placed four subsamples of 25 seeds on autoclaved filter paper moistened with distilled water, which were fit within gerboxes with dimensions of $11.0 \times 11.0 \times 3.5 \mathrm{~cm}$. These boxes were left in germination chambers of BOD type (Biochemical Oxygen Demand), set at a constant temperature of $35^{\circ} \mathrm{C}$, once it had been the best temperature obtained in previous trials. After sowing, we made a daily description of germination process and seedling morphological characterization over a period of 20 days. In short, we evaluated the germination type, sequence and timing of the development of each seedling part, the presence of trichome and their distribution, besides the coloring of structures, all according to Pereira et al. (2008).

For germination test, we performed a prior seed asepsis, by immersing them into $70 \%$ alcohol for one minute; then, they were rinsed in distilled water (Oliveira et al. 2012). After that, we placed them on a filter paper previously autoclaved and dampened with distilled water, using an amount of water 2.5 times the paperweight (BRASIL, 2009). The test was also conducted in BOD chambers at different constant temperatures of $15^{\circ} \mathrm{C}, 25^{\circ} \mathrm{C}, 35^{\circ}$ $\mathrm{C}, 45^{\circ} \mathrm{C}$ and an alternating one of $20-30{ }^{\circ} \mathrm{C}$, under different qualities of light (white light, red light, farred light) or under light absence. The different light qualities were obtained by a combination of red and blue cellophane paper. For red light, we coated the gerboxes with two red cellophane sheets. For far-red light, we overlapped red and blue cellophane sheets. For white light, we used transparent gerboxes covered by a transparent cellophane sheet to hold moisture. The absence of light was obtained by using black gerboxes. Then, observations were carried daily, considering germinated seeds, those with apparent primary root curvature. The statistical design was completely randomized in a $5 \times 4$ factorial scheme, with four replications of 25 seeds.

Seeds asepsis, experiment setting, as well as daily germination counting were carried out under green safe light, obtained by enveloping fluorescent lamps $(20$ w) with green cellophane sheets (ALENCAR, 2012).

From daily counting, we could calculate germination percentage and speed index (GSI). Results underwent analysis of variance and means were compared by the Tukey's test at 5\% probability. For analysis of variance, germination percentage data were transformed into arcsine $\sqrt{ } \% / 100$.

\section{RESULTS AND DISCUSSIONS}

A. costantinii fruit come from inferior ovary and are berry-type, fibrous, odorless, polyspermic, indehiscent, tricarpellate, triloculate with central placentation, triangular apex and globous dilated portion provided with tiny whitish trichrome visible to the naked eye (Figures 1A and B). The epidermis presents greenish outer surface when unripe, acquiring a dark-wine coloration with ripening. 


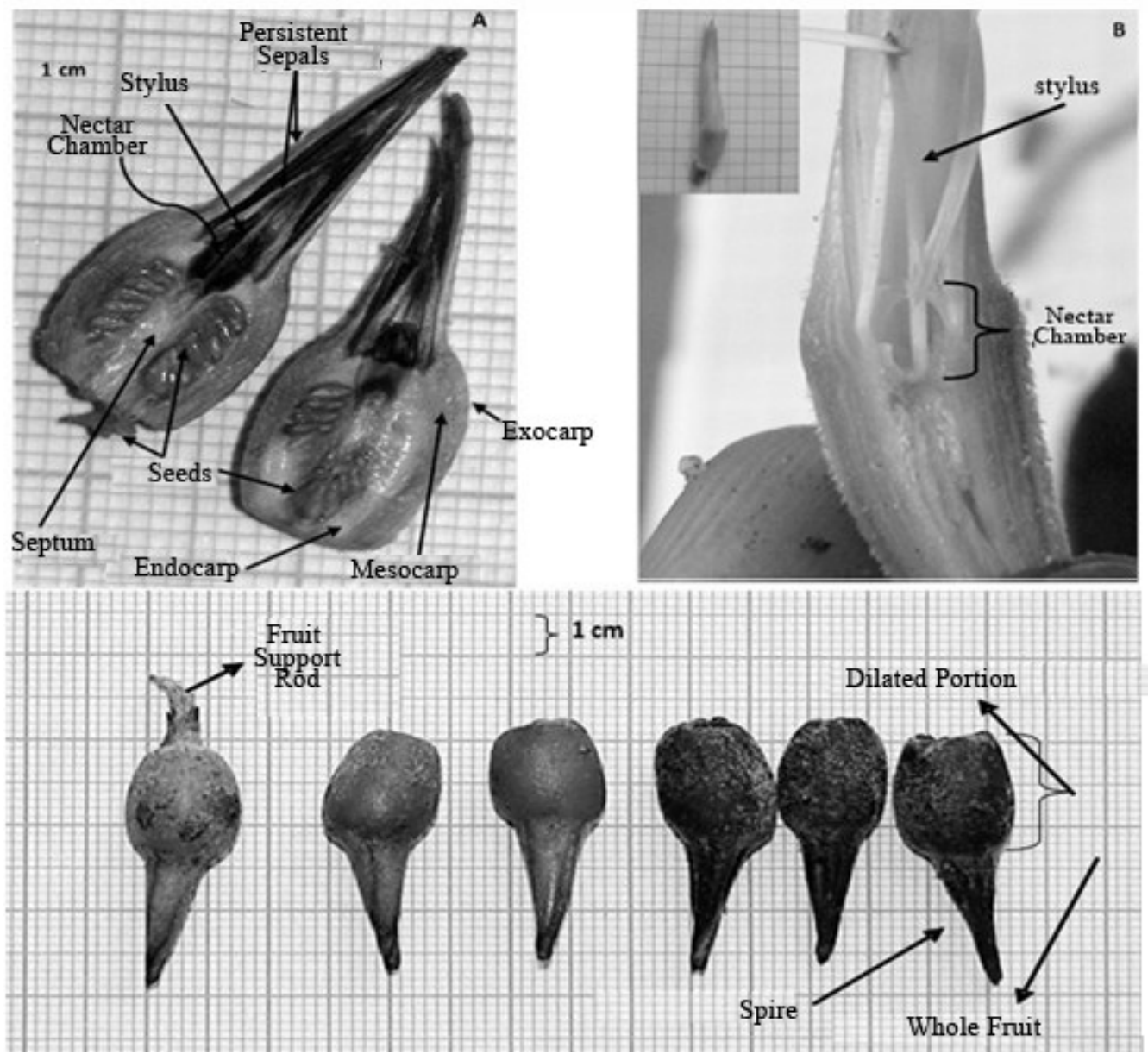

Figure 1. Longitudinal section, showing internal and external flower structures (A) and fruit structures (B), fruit of Aechmea costantinii (Mez) L. B. Sm. (Bromeliaceae) at different ripeness stages (C) collected from a permanent preservation area belonging to the Cachoeira do Meirim Sugar and Ethanol Plant in the State of Alagoas, Brazil.

Typical floral elements, such as nectar chamber, stylus and persistent sepals were identified inside fruit (Figures 1A and B); these macroscopic structures are very helpful in taxonomic studies. Such knowledge becomes particularly important in species identification at laboratories and/ or nurseries where only fruits and seeds are left for routine analysis.

At ripeness, the whole fruit were $28.2 \mathrm{~mm}$ and $14.6 \mathrm{~mm}$ in total length and dilated portion, respectively, and had average diameter of $8.9 \mathrm{~mm}$. These dimensions varied little, presenting a maximum variation coefficient (VC) of $13.7 \%$ (Table 1). On the other hand, the number of fruits per plant and seeds per fruit showed relative high values for standard deviation and VC, indicating wide variation of these traits within the study population (Table 1).

Table 1. Descriptive statistics of length, diameter and weight of fruits and seeds, number of fruits per plant and number of seeds per fruit of Aechmea costantinii (Mez) L. B. Sm. (Bromeliaceae) collected from a permanent preservation area belonging to the Cachoeira do Meirim Sugar and Ethanol Plant in the State of Alagoas, Brazil.

\begin{tabular}{|c|c|c|c|c|c|c|}
\hline & \multicolumn{2}{|c|}{ Lenght (mm) } & \multicolumn{4}{|l|}{ Diameter $(\mathrm{mm})$} \\
\hline Variable & whole fruit & dilated portion & dilated portion & weight $(\mathrm{g})$ & NFP & N S F \\
\hline Mean & 28.2 & 14.6 & 8.9 & 4.4 & 204.2 & 72.8 \\
\hline Mode & 28.9 & 13.2 & 7.3 & 2.2 & 158.0 & 56.0 \\
\hline Median & 28.3 & 14.2 & 9.4 & 5.0 & 179.0 & 67.0 \\
\hline minimum & 23.6 & 12.2 & 6.8 & 2.2 & 84.0 & 31.0 \\
\hline maximum & 33.1 & 17.6 & 10.4 & 7.0 & 367.0 & 109.0 \\
\hline Standard deviation & 2.5 & 1.4 & 1.2 & 1.5 & 70.8 & 20.8 \\
\hline Variation coefficient $(\%)$ & 9.1 & 10.0 & 13.7 & 34.5 & 34.7 & 28.6 \\
\hline
\end{tabular}


When unripe, fruit are green, solid but get soft at ripeness. This consistency change facilitates detachment from mother-plant. After being harvested, we observed that part of the fruit base tissue remains on the inflorescence, forming an opening (hole), from where seeds were released after light pressuring on dilated portion.

At harvest, fruit show a dark-wine color and absence of odors. These observations are supported by Snow (1981), who reported that fruit adapted to dispersal by birds (ornithochory) have conspicuous and quite visible colorations (red, orange and blue) and have virtually no odor.

In the field, we observed that certain birds used the pyramidal structure on the fruit top to facilitate removal, which is consistent with observations made by Gorbet al. (2000), who cited the relationship between fruit and birds within the seed and fruit dispersion process.

Besides the fruit morphological aspects (Figure 2), inflorescence also seems to play major role in attracting dispersing agents, so they are usually eye-catching, conspicuous coloration and with reddish bracts and yellow flowers.

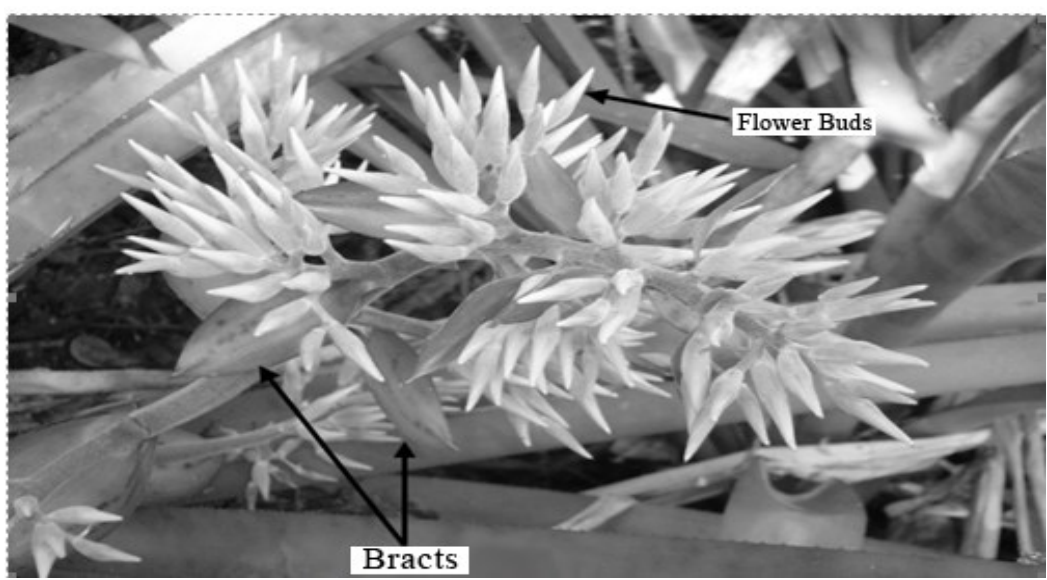

Figure 2. Inflorescence of Aechmea costantinii (Mez) L. B. Sm. (Bromeliaceae) showing bracts and flower buds collected from a permanent preservation area belonging to the Cachoeira do Meirim Sugar and Ethanol Plant in the State of Alagoas, Brazil.

The elliptical seeds are $2.67 \mathrm{~mm}$ in length and $0.77 \mathrm{~mm}$ in width, on average. The thousand seed weight was $1.332 \mathrm{~g}$ at $21.3 \%$ moisture, totaling 750.750 seeds per kilogram. The seed coat is smooth and uneven coloring with dark brown apex and middle portion, and reddish-brown bottom edge, in which primary root-protrusion grows. These propagating structures do not exhibit any kind of appendix, only a colorless and transparent mucilage was observed involving the integument thereof. The presence of the mucilage sheath may be advantageous assisting in seed fixation to suitable places for germination, or protecting and maintaining their moisture content, contributing to seeds' greater longevity, as mentioned by Paula and Silva (2004). Conversely, mucilage may also be disadvantageous, as observed by Melchior et al. (2006), in seeds of Campomanesia adamantium (Cambess) O. Berg (Myrtaceae), in which such structure contribute to fungal development, leading to seed quality reduction or even releasing inhibitory substances that may impair germination and seedling development.

The embryo is whitish, small $(1 / 4$ to half seed size), and parallel to reserve tissue within the seed base. The reserve tissue has mealy texture of the same embryo color, and occupies most of the seminal chamber. Such information becomes very useful in laboratory tests, assisting seed cuts and handlings (FELIPPI et al., 2012).

Seeds of $A$. costantinii ripe fruit are brown; however, these seeds vary in coloration ranging from light brown to dark red throughout ripeness process. Pinã-Rodrigues and Aguiar (1993) noted that fruit and seed ripening can be identified by change of colors, and when both are synchronized, becomes an effective index of ripeness. For this species, fruit and seed color changes were synchronous, i.e. this feature can be a visual indication of optimal harvest time for fruit and seeds, when aiming to produce seedlings.

The timing between fruit and seed ripening may play an important role in attracting dispersers at the right moment (JANZEN, 1983). This type of synchronization, according to Piña-Rodrigues and Aguiar (1993), may be valid to determine the best time for fruit harvesting, using the seeds to produce seedlings. These authors mentioned that fruit coloring has an ecological role as indicative of seed maturation. Since it can act as warning mechanism or attractive for biotic dispersers, essential for the survival of zoochoric species. Regarding the postseminal development, we observed seed swelling in the early days, and root protrusion visible at the narrowest seed portion (micropyle), where seed coat 
has taken a saw-toothed appearance (Figure 3A). Primary root was vigorous, cylindrical, and bright whitish, showing positive gravitropism, visible root cap, and root hairs on the sixth day (Figure 3B).
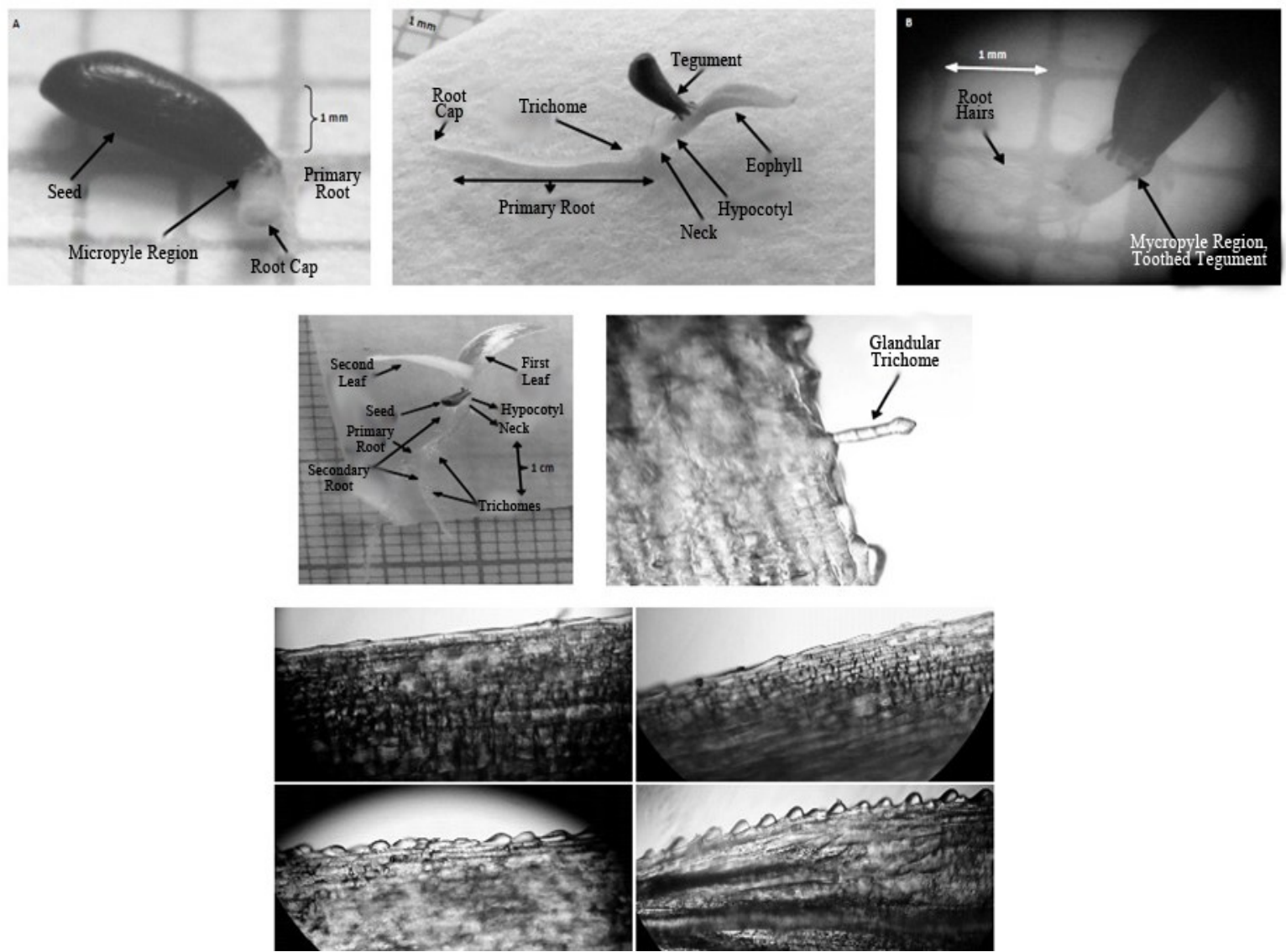

Figure 3. Different stages of post seminal development of Aechmea costantinii (Mez) L. B. Sm. (Bromeliaceae) collected from a permanent preservation area belonging to the Cachoeira do Meirim Sugar and Ethanol Plant in the State of Alagoas, Brazil.

From the tenth day after sowing, hypocotyl could be distinguished by root elongation, being short and greenish (Figure 3C). At this stage, there is also the presence of the first eophyll, also greenish.

A small swelling at the hypocotyl base, plus the presence of root hairs within the transition region enabled the external distinction between hypocotyl and primary root (Figure 3C), referred to as neck. This region is an element of identification in seedlings, steadily on all species.

The elongated primary roots showed concentration of root hairs on the upper portion, near the neck, distributing sparsely along the root. After 15 days, seedlings had well developed root system, with primary and secondary roots endowed by root hairs distributed along its entire length (Figure 3D). Seedlings started to present a rosette form, with the emergence of the third leaf on the seventeenth day after sowing. After 20 days, glandular hairs started to grow on the adaxial and abaxial leaf surfaces (Figure $3 \mathrm{E})$; these structures absorb water and nutrients and enhance seedling survival on dry and/ or oligotrophic substrates, both in terrestrial and epiphytic environments (MANTOVANI; IGLESIAS, 2002).

After 20 days growth, we could observe a row of cells at varied development stages on the leaf surface of $A$. costantinii seedlings, which might be related to the spinescent margin development. Such growth process can be seen in Figure 3 (F and G), where it is possible to note that these cells evolve from a flat shape to a rounded one, due to their swelling, and subsequently showing a spiky edge.

The studied species has epigeal germination, in which the first eophyll rose above substrate level during the hypocotyl elongation. Cryptocotyledonary, wherein cotyledon was not detached from seed integument while keeping haustorium inside seed remains. According to Garwood cited by Pereira et al. (2008) this is structure is the haustorial cotyledon and is responsible for the absorption and transfer of endosperm reserves for seedling growth. The emerged cotyledons are considered foliaceous and become photosynthetic; yet non-emerged ones are considered as reserve. Epigeal germination was also observed in some species of Aechmea Ruiz \& Pav, Quesnelia Gaudich, Billbergia Thumb, Neoregelia, Nidularium Lem, Orthophytum Beer, Canistrum E. Morem, Porteae Brongn, belonging to the subfamily 
Bromelioideae (PEREIRA, 1988), and epigeal cryptocotylar in seeds of Dyckia goehringii E. Gross \& Rauh (DUARTE et al., 2010). According to Boyd (1932), this type of germination of bromeliads is related to epiphytism, as well as absence or presence of rare vascular bundles in sheath cotyledon.

Table 2 shows that there was significant interaction between light quality and temperature, both on germination percentage and speed index (GSI). Moreover, germination was null at both $15^{\circ} \mathrm{C}$ and $45^{\circ} \mathrm{C}$; however, those left to germinate at $15^{\circ} \mathrm{C}$ remained intact without deterioration signs. In contrast, those seeds left under $45{ }^{\circ} \mathrm{C}$ had darkening and softening of the seed tissue, pointing to an advanced deterioration stage. These results are in agreement with Marcos Filho (2005), who reported that high temperatures may trigger seed deterioration process, may cause, for example, denaturation of essential proteins for seed germination; while low temperatures inhibit germination, and can make it longer or even null.

Table 2. Percentage (G) and speed index (GSI) of seed Aechmea costantinii (Mez) L. B. Sm (Bromeliaceae) collected from a permanent preservation area belonging to the Cachoeira do Meirim Sugar and Ethanol Plant in the State of Alagoas, Brazil under different temperatures and light qualities.

\begin{tabular}{|c|c|c|c|c|c|c|c|c|}
\hline \multirow[b]{3}{*}{ Temperature $\left({ }^{\circ} \mathrm{C}\right)$} & \multicolumn{8}{|c|}{ Light quality } \\
\hline & \multicolumn{2}{|c|}{ White light } & \multicolumn{2}{|c|}{ Red light } & \multicolumn{2}{|c|}{ Far red light } & \multicolumn{2}{|c|}{ Dark condition } \\
\hline & $\mathrm{G}(\%)$ & GSI & $\mathrm{G}(\%)$ & GSI & $\mathrm{G}(\%)$ & GSI & $\mathrm{G}(\%)$ & GSI \\
\hline 15 & - & - & - & - & - & - & - & - \\
\hline 25 & $70.8 \mathrm{ABa}$ & $11.0 \mathrm{Ba}$ & $69.7 \mathrm{Aa}$ & $10.7 \mathrm{Ba}$ & $71.3 \mathrm{Aa}$ & $11.0 \mathrm{Ba}$ & $76.0 \mathrm{Aa}$ & $9.4 \mathrm{Aa}$ \\
\hline 35 & $83.9 \mathrm{Aa}$ & $15.0 \mathrm{Aa}$ & $74.2 \mathrm{Aa}$ & 14.7 Aa & $78.7 \mathrm{Aa}$ & $14.5 \mathrm{Aa}$ & $0.5 \mathrm{Cb}$ & $0.5 \mathrm{Bb}$ \\
\hline 45 & - & - & - & - & - & - & - & - \\
\hline $20-30$ & $56.9 \mathrm{Bb}$ & $11.7 \mathrm{Bb}$ & $77.8 \mathrm{Aa}$ & $14.0 \mathrm{Aa}$ & $72.2 \mathrm{Aa}$ & $13.3 \mathrm{Aab}$ & $52.2 \mathrm{Bb}$ & $8.0 \mathrm{Ac}$ \\
\hline \multicolumn{7}{|c|}{ Value of " F " to light (L) } & $43.4^{* *}$ & $57.2 * *$ \\
\hline \multicolumn{7}{|c|}{ Value of " F " to temperature $(\mathrm{T})$} & $76.6^{* *}$ & $82.0^{* *}$ \\
\hline \multicolumn{7}{|c|}{ Value of " F " to interaction (L X T) } & $12.4 * *$ & $10.9 * *$ \\
\hline \multicolumn{7}{|l|}{$\mathrm{CV}(\%)$} & 18.4 & 25.9 \\
\hline
\end{tabular}

Average followed by the same letter, capital in the column and small in the line, do not differ statistically by Tukey test at $5 \%$ probability. Germination percentage data were transformed into arcsine $\sqrt{ } \% / 100$.

It is known that extreme ambient temperatures cause internal damage to the seeds that impair germination, being sometimes irreversible. Heat speed up the molecules' movement, chemical bonds linking the atoms become weaker and lipid layers of the biomembranes become more fluid. In addition, low temperatures decrease the metabolic rates derived from lack of activation energy for the enzyme system (FLOSS, 2008). Such responses can be observed in Bromelia serra Griseb, for which temperatures of $15{ }^{\circ} \mathrm{C}$ and $20{ }^{\circ} \mathrm{C}$ inhibit germination (KLEKAILO et al., 2012). Even though high temperatures decreases water viscosity and increases water kinetic energy, benefitting seed soaking and metabolic rate rise (MARCOS FILHO, 2005); extremely high temperatures disrupt enzyme system and cause protein denaturation besides cellular membrane system breakdown. Similar results were also observed in Alcantarea imperialis (Carriere) Harms, Vriesea heterostachys (Baker) L. B. Sm. and Pitcairnia flamme Lindl., wherein the temperature of $15{ }^{\circ} \mathrm{C}$ provided germination of $15 \%$ seeds, whereas the temperature of $40{ }^{\circ} \mathrm{C}$ exerted negative influence on the germination of these seeds (PEREIRA et al., 2009).
The temperatures of $25^{\circ} \mathrm{C}$ and $35^{\circ} \mathrm{C}$ provided the highest germination percentage (Table 2), though seeds under $35{ }^{\circ} \mathrm{C}$ had the highest GSIs, in presence of light of any quality.

Tropical forests may have wide variation in light regime, from a dense shading as in understory (low red/ far-red ratio), up to intense radiation as in clearings (high red/ far-red ratio). This variation makes the environment more or less favorable to seed germination of various plant species. As observed results, the freshly harvested seeds of $A$. costantinii germinate in places with a wide variation of light, i.e. these seeds are able to explore different red / far-red ratios. Therefore, these seeds can germinate in clearings of different sizes, where direct sunlight exposure might be short, as well as in environments where light is filtered by the canopy.

The red/ far-red ratio can be drastically reduced under canopy covering compared to values under full sun. Hence, the red/ far-red ratio is a significant factor, by which plants can detect micro environmental changes both under shading by vegetation canopy as by neighboring plants (TAIZ; ZAIGER, 2013).

As shown in Table 2, it can be seen that 
germination was null in the dark at $35^{\circ} \mathrm{C}$. Whereas the other temperatures stimulated germination, with higher levels for those exposed to $25^{\circ} \mathrm{C}$.

Upon adopting the criterion proposed by Klein and Philip (1991), in which a photoblastic trait can be "preferential" if any germination occurs in the dark or "absolute when germination is null in the dark. Given this, we observed that the seeds of A. costantinii have an absolute behavior at $35^{\circ} \mathrm{C}$, at which the largest germination rates were achieved. On the other hand, under an alternating temperature of 20-30 ${ }^{\circ} \mathrm{C}$, seeds had a preferential behavior (Table 2). Therefore, we can infer that the germination of $A$. costantinii seeds under dark conditions depends on thermal conditions; as long as at $25{ }^{\circ} \mathrm{C}$, there was no statistical differences for germination percentage with or without light; in this case, seeds may be considered neutral to light.

Our results show that $A$. costantinii fruit show great variation in the number of seeds and fruit per plant. The elliptical seeds with basal-like embryo have epigeal germination with fanerocotylar seedlings. Under laboratory conditions, germination tests can be conducted at a constant temperature of $35^{\circ} \mathrm{C}$ in the presence of light.

\section{CONCLUSIONS}

The $A$. costantinii fruit are polyspermic of the tricarpellate/triloculate type. They are indehiscent and originated from inferior ovary with an average of 73 elliptical and mucilaginous seeds with basal embryo.

The germination is epigeal, with greater intensity and speed at $35{ }^{\circ} \mathrm{C}$, regardless of the presence and quality of light.

\section{REFERENCES}

ALENCAR, N. L. M; GOMES-FILHO, E; INNECCO, R. Cereus jamacaru seed germination and initial seedling establishment as a function. Scientia Agricola, Piracicaba, v. 69, n. 1, p. 70-74, 2012.

ÁQUILA, M. E. A. Tipos de diásporos e suas origens. In: FERREIRA, A. G; BORGHETTI, F. (Ed.) Germinação: do básico ao aplicado. Porto Alegre, RS: ARTMED, 2004. p. 68-92.

ASSIS, J. S. Biogeografia e conservação da biodiversidade: projeções para Alagoas. 1. ed. Maceió, AL: Edições Catavento, 2000. 200 p.

BENZING, D. H. Bromeliaceae: profile of an adaptative radiation. 1 ed. Cambridge, United Kingdon: Cambridge University Press, 2000. 248 p.
BOYD, L. Monocotylous seedlings. Morphological studies in the post-seminal development of the embryo. Transactions and Proceedings of the Botanical Society of Edinburgh, Edinburgh, v. 31, n.1, p. 5-224, 1932.

BRASIL. Regras para Análise de Sementes. Ministério da Agricultura e Reforma Agrária. Brasília: SNDA/DNPV/ CLAV. 2009. 398 p.

DUARTE, E. F. et al. Características físicas e germinação de sementes de Dickia goehringii Gross e Rauh (Bromeliaceae) sob diferentes temperaturas. Pesquisa Agropecuária Tropical, Goiania, v. 40, n. 1, p. 422-429, 2010.

FELIPPI, M. et al. Fenologia, morfologia, e análise de sementes de Cordia trichotoma (Vell.) Arrab. Ex. Steud. Ciência Florestal, Santa Maria, v. 22, n. 3, p. 631-641, 2012.

FLOSS, E. L. Fisiologia das plantas cultivadas: O estudo do que está por trás do que se vê. 4. ed. Passo Fundo, RS. Universidade de Passo Fundo, 2008. 536 p.

FONTENELLE, A. C. F.; ARAGAO, W. M.; RANGEL, J. H. A. Biometria de frutos e sementes de Desmanthus virgatus (L) Willd Nativas de Sergipe. Revista Brasileira de Biociências, Porto Alegre, v. 5, n. 1, p. 252-254, 2007.

GIVNISH T. J. et al. Phylogeny, adaptive radiation, and historical biogeography of Bromeliaceae inferred from ndh F sequence data. Aliso, Rancho Santa Ana Botanic Garden Aliso, v. 23, n. 1, p. 3-26, 2007.

GORB, S. N; GORB, E. V; PUNTTILA, P. Effects of redispersal of seeds by ants on the vegetation pattern in a deciduous forest: A case study. Acta Oecologica, Dorchester, v. 21, n. 4-5, p. 293-301, 2000 .

JANZEN, D. H. Seed and pollen dispersal by animals: convergence in the ecology of contamination and sloppy harvest. Biological Journal of the Linnean Society, London, v. 20, n.1, p. 103-113, 1983.

KLEIN, A; FELIPPE, G. M. Efeito da luz na germinação de sementes de ervas invasoras. Pesquisa Agropecuária Brasileira, Brasília, v. 26, n. 7, p. 955-966, 1991.

KLEKAILO, G. N; TUESCA, D; BARBERIS, I. M. Efectos de la temperatura, el ambiente lumínico y laescarificación sobre lagerminación de semillas de Bromelia serra griseb. (bromeliaceae). Revista Brasileira de Sementes, Londrina, v. 34, n. 4, p. 605 
$-612,2012$

LUTHER. H. E. An alfabetical listo of Bromeliad binomials. 11. ed. The Marie Selby Botanical Gardens Sarasota, Flórida, USA. The Bromeliad Society International, 2008. 109 p.

MANTOVANI, A; IGLESIAS, R. R. Bromélias terrestres na restinga de Barra de Maricá, RJ: influência sobre o microclima, o solo e a estocagem de nutrientes em ambientes de borda de moitas. Leandra, Rio de Janeiro, v. 16, n. 1, p. 17-36, 2002.

MARCOS FILHO, J. Fisiologia de sementes de plantas cultivadas. 1. ed. Piracicaba, SP: FEALQ, $2005.425 \mathrm{p}$.

MELCHIOR, S. J. et al. Colheita e armazenamento de sementes de gabiroba (Campomanesia adamantium Camb.-Myrtaceae) e implicações na germinação. Revista Brasileira de Sementes, Pelotas, v. 28, n. 3, p. 141-150, 2006.

OLIVEIRA, S. S. C; ARAUJO NETO, J. C; FERREIRA, V. M. Caracterização morfométrica de sementes e plântulas e germinação de sementes de Anadenanthera macrocarpa (Benth) Brenan. Ciência Florestal, Santa Maria, v. 22, n. 2, p. 643$653,2012$.

PAULA, C. C; SILVA, H. M. P. Cultivo prático de bromélias. 2. ed. Viçosa, MG: UFV, 2001. 73 p.

PEREIRA, A. R. et al. Comportamento germinativo de espécies epífitas e rupícolas de Bromeliaceae do Parque Estadual do Ibitipoca, Minas Gerais, Brasil. Revista Brasileira de Botânica, São Paulo, v. 32, n. 4, p. 827-838, 2009.

PEREIRA, A. R. et al. Morfologia de sementes e do desenvolvimento pós-seminal de espécies de Bromeliaceae. Acta Botânica Brasilica, Belo Horizonte, v. 22, n. 4, p. 1150-1162, 2008.

PEREIRA, T. S. Bromelioideae (Bromeliaceae): Morfologia do desenvolvimento pós-seminal de algumas espécies. Arquivos do Jardim Botânico do Rio de Janeiro, Rio de Janeiro, v. 29, n. 1, p. 115154, 1988.

PIÑA-RODRIGUES, F. C. M; AGUIAR, I. B. Maturação e dispersão de sementes. In: AGUIAR, I. B; PIÑA-RODRIGUES, F. C. M; FIGLIOLIA, M. B. (ed.). Sementes Florestais Tropicais. Brasília: ABRATES, 1993. v. 1, cap. 5, p. 215-274.

RIOS, P. A. F; SILVA, J. B; MOURA, F. B. P. Visitantes florais de Aechmea costantinii (MEZ) LB. $\mathrm{Sm}$. (bromeliaceae) em um remanescente da mata atlântica do nordeste oriental. Biotemas,
Florianópolis, v. 23, n. 4, p. 29-36, 2010.

SILVA, B. M. S.; MÔRO, F. V. Aspectos morfológicos do fruto, da semente $\mathrm{e}$ desenvolvimento pós-seminal de faveira (Clitoria fairchildiana R. A. Howard. - Fabaceae). Revista Brasileira de Sementes, Londrina, v. 30, n. 3, 2008.

SIQUEIRA FILHO, J. A; LEME, E. M. C. An addition to the genus Canistrum: a new combination for an old species from Pernambuco and a new species from Alagoas. Journal of the Bromeliad Society, Orlando, v. 52, n. 3, p. 105-121, 2002.

SNOW, D. H. Tropical frigivorous birds and their food plants: a world survey. Biotropica, Lawrence, v. 13, n. 1, p. 1-14, 1981.

TAIZ, L; ZEIGER, E.. Fisiologia vegetal. 5. ed. Porto Alegre, RS: ARTMED. 2013, 918 p. 